\title{
Seed germination characteristics of Phillyrea angus- tifolia L. and P. latifolia L. (Oleaceae), two Mediterra- nean shrub species having lignified endocarp
}

\author{
S. Mira, L. Veiga-Barbosa, F. Pérez-García
}

Mira S., Veiga-Barbosa L., Pérez-García F., 2015. Seed germination characteristics of Phillyrea angustifolia L. and P. latifolia L. (Oleaceae), two Mediterranean shrub species having lignified endocarp. Ann. For. Res. 58(1): 27-37.

Abstract. The aim of this study was to determine the germination characteristics of Phillyrea angustifolia L. and P. latifolia L. seeds in order to develop an optimized propagation protocol for Phillyrea species. Seeds of $P$. angustifolia and $P$. latifolia were collected from wild plants growing in Cáceres province (CW Spain) and Andalucía (S Spain), respectively. Percentage of water uptake for $P$. latifolia seeds was calculated. Seeds with and without endocarp were germinated at different constant and alternating temperatures. Seeds without endocarp were soaked in distilled water or gibberellic acid, and then set to germinate. Seeds with endocarp of both species were stratified at $5{ }^{\circ} \mathrm{C}$ for 30 or 90 days and then the endocarp was completely removed from the seeds before they were sowed. Chemical scarification with sulfuric acid and mechanical scarification were tested on $P$. angustifolia seeds with endocarp. Phillyrea endocarp was permeable to water, since Phillyrea seeds with endocarp imbibed water, but water uptake was faster when the endocarp was removed. Moreover, the encodarp could interfere mechanically in the emergence of the radicle, since seed germination of Phillyrea species was promoted by the complete removal of the lignified endocarp surrounding each seed. Optimal germination temperature for both species was $15^{\circ} \mathrm{C}$, and lower temperatures produced secondary dormancy. Soaking in distilled water or gibberellic acid did not significantly enhance seed germination. Cold stratification and chemical scarification treatments were detrimental for seed germination. Keywords cold stratification, Phillyrea species, treatments before sowing, seed germination, seed scarification, lignified endocarp.

Authors. Sara Mira (sara.mira@upm.es), Félix Pérez-García - Department of Plant Biology, School of Agronomics Engineering, Technical University of Madrid, Madrid, Spain; Luciana Veiga-Barbosa - Department of General Biology, Federal University of Bahia, Salvador, Bahia, Brazil.

Manuscript received September 29, 2014; revised January 26, 2015; accepted January 30, 2015; online first February 05, 2015. 


\section{Introduction}

Seed germination is the most sensitive stage in the plant ability for spatial colonization (Baskin \& Baskin 1998). In Mediterranean ecosystems, evergreens repeatedly face important environmental constraints and cope with extreme summer droughts, extensive fires and soil erosion (Demmig-Adams \& Adams 1996, Chaves et al. 2002, Dimitrakopoulos et al. 2013). Climate change models project a reduction in total precipitation and drier summers (Christensen et al. 2007) and associated increase in fire hazard in Mediterranean regions (Piñol et al. 1998, Pausas et al. 2008). Therefore, in the Mediterranean areas, plant regeneration strategies and environmental factors are closely interlinked, and knowledge on seed germination of Mediterranean species would be fundamental for the ecosystem conservation and for directing regeneration efforts (Varela 2000, Pardos et al. 2005).

Phillyrea L. is a genus of 2 species in the Oleaceae family: P. angustifolia L. and P. latifolia L. (Andrés 2011). They are evergreen shrubs very representative of the Mediterranean forest and with high importance in the ecological dynamics (Kutbay \& Kilinç, 1994, Herrera et al. 1994). Many of the natural and semi-natural forests containing $P$. angustifolia are under decline due to the impact of anthropogenic disturbance, and restoration efforts to address this are underway in many countries. Phillyrea species are thermophilic and with low watering requirements, and have been recently considered suitable for landscaping purposes for their little maintenance needs (De Marco et al. 2005). Phillyrea species are, therefore, of growing economical importance. The species can be propagated by seed germination and vegetatively (Piotto \& Di Noi 2003), but plant rooting is difficult (Catalán 1991). Phillyrea species produce fleshy-fruits (drupes), usually containing a single seed enclosed by a lignified endocarp. Typically, a lignified endocarp may be water-impermeable, thereby preventing im- bibition and thus seed germination (Baskin \& Baskin 1998, Baskin et al. 2002). Due to the presence of a lignified endocarp, it has been suggested that Phillyrea species may presents physical dormancy (García-Fayos et al. 2001, Takos \& Efthimiou 2003), however, water absorption of the endocarp and dormancy break protocols have not been established. Within the Oleaceae family, the genus Olea is characterized by physiological dormancy and a woody endocarp that prevents the expansion of the embryo (Morales-Sillero et al. 2012), and even after total removal of the endocarp, seed germination is slow and erratic (Mitrakos \& Diamantoglou 1984). Seed germination of Phillyrea species was showed to be poor and unreliable in nurseries (Catalán 1991). This erratic germination of Phillyrea could have an effect on the presence of plants at different physiological phases, complicating their management and commercialization.

The general aim of this work was to investigate the seed germination behavior of Phillyrea species in order to develop an optimized propagation protocol. The specific objectives of the present study were to determine (i) the optimal temperature requirement for germination of $P$. angustifolia and $P$. latifolia seeds, (ii) the effect of treatments before sowing on germination for both species, (iii) the water uptake capacity of $P$. latifolia seeds with and without endocarp and (iv) the effect of different scarification treatments on germination of $P$. angustifolia seeds.

\section{Materials and methods}

\section{Plant material}

Ripe fruits of $P$. angustifolia and $P$. latifolia were collected in 2011 from wild plants growing in Cáceres province (CW Spain) and Andalucía (S Spain), respectively. To carry out the trials in which seeds without endocarp were used, the endocarp of the fruit was completely 
removed using pliers and a scalpel. Seeds were manually cleaned, kept in paper bags, and then stored dry under laboratory conditions (at $\sim 23$ ${ }^{\circ} \mathrm{C}$ under darkness, $35 \%$ relative humidity) until the start of trials. Visible damaged seeds were excluded from experiments.

\section{Effect of temperature regimes on seed ger- mination}

Seeds without endocarp of $P$. angustifolia and $P$. latifolia were tested for germination at different constant temperatures $\left(5^{\circ} \mathrm{C}, 10^{\circ} \mathrm{C}, 15\right.$ ${ }^{\circ} \mathrm{C}, 20{ }^{\circ} \mathrm{C}, 25^{\circ} \mathrm{C}$ ), with a 16 -h light photoperiod (provided by cool white fluorescent tubes with an irradiance of $35 \mu \mathrm{mol} \mathrm{m} \mathrm{m}^{-1}$ ), and the alternate temperature regimes of $20 / 7{ }^{\circ} \mathrm{C}$ and $25 / 15^{\circ} \mathrm{C}$ (the highest temperature for $16 \mathrm{~h}$ in light and the lowest one for $8 \mathrm{~h}$ in dark). In each trial, four replicates of 25 seeds each for $P$. angustifolia and two replicates of 30 seeds each for $P$. latifolia were tested for germination on top of two sheets of filter paper (previously moistened with $3.5 \mathrm{~mL}$ of distilled water) in 7 -cm-diameter glass Petri dishes. Filter papers were rewetted regularly with distilled water, as required. Dishes were checked three times a week and germinated seeds were counted and removed. Seeds were considered germinated on emergence of the radicle from the seed coat. The initial incubation period was 35 days for P. angustifolia and 55 days for P. latifolia, which showed a slower germination. To study the effect of high and low temperatures of incubation on seed germination at the optimum conditions, after incubation at different temperatures, non-germinated seeds were transferred to $15^{\circ} \mathrm{C}$ (which was the temperature that induced the highest germination percentages). Thus, non-germinated seeds of $P$. angustifolia after 35 days at $5{ }^{\circ} \mathrm{C}, 25^{\circ} \mathrm{C}$ and $25 / 15^{\circ} \mathrm{C}$ were transferred to $15{ }^{\circ} \mathrm{C}$ and then incubated for another 35-day period. Non-germinated seeds of $P$. latifolia after 55 days at $10^{\circ} \mathrm{C}, 20^{\circ} \mathrm{C}$, $25{ }^{\circ} \mathrm{C}$ and $25 / 15^{\circ} \mathrm{C}$ were transferred to $15{ }^{\circ} \mathrm{C}$ and then incubated for another 137-day period.
P. latifolia assays were also performed with seeds having intact endocarp. $P$. angustifolia seeds with endocarp where not included on the assay due to the scarcity of seed material. In all trials, seeds that had not germinated at the end of the incubation period were opened to determine whether the seed was empty. If so, they were excluded from calculation of final germination percentages (Baskin \& Baskin 1998). The number of empty seeds was always equal or less than $5 \%$ of the total seeds.

\section{Effect of treatments before sowing on seed germination}

3 treatments before sowing were applied by using seeds of $P$. angustifolia and $P$. latifolia. 4 replicates of 25 seeds each were tested for each treatment: (i) soaking in distilled water. Seeds without endocarp were soaked in distilled water at room temperature $\left(\sim 23{ }^{\circ} \mathrm{C}\right)$ for 24 or 72 $\mathrm{h}$, (ii) soaking in gibberellic acid (GA $)_{3}$. Seeds without endocarp were soaked in a $\mathrm{GA}_{3}$ solution $\left(1000 \mathrm{mg} \mathrm{L}^{-1}\right)$ at room temperature $(\sim 23$ ${ }^{\circ} \mathrm{C}$ ) for $24 \mathrm{~h}$, (iii) cold stratification. Seeds with endocarp were stored in moist vermiculite under darkness at $5{ }^{\circ} \mathrm{C}$ for 30 and 90 days. After the cold stratification period, the endocarp was completely removed from the seeds before they were sowed.

After these three treatments, seeds were tested to germinate at $15{ }^{\circ} \mathrm{C}$ under a 16 -h light photoperiod for 65 days. Untreated seeds without endocarp were sown in the same conditions and they were used as control.

\section{Water uptake during seed soaking}

To determine water uptake capacity during seed soaking, 2 replicates of 25 P. latifolia seeds (with and without endocarp) each were weighted and then placed in Petri dishes on filter paper moistened with distilled water. After 1, 2, 24, 48 and $72 \mathrm{~h}$ of imbibition, seeds were quickly surface-dried with filter paper and then reweighted. Percentage of water uptake (mean 
\pm standard error) was calculated as the amount of water adsorbed by seeds relative to the initial seed weight. Due to the scarcity of seed material this assay could not be done with $P$. angustifolia seeds.

\section{Effect of scarification treatments on seed germination}

4 scarification treatments were compared on $P$. angustifolia seeds with endocarp before they were sowed at $15{ }^{\circ} \mathrm{C}$ under a 16 -h light photoperiod for 75 days. 4 replicates of 25 seeds each were tested for each scarification treatment: (i) endocarp totally removed. Endocarp was carefully removed using pliers and a scalpel, (ii) endocarp partially scarified. Endocarp was cracked with pliers but it was not completely removed from seed, (iii) sulfuric acid $(6 \mathrm{~h})+$ hot water $\left(80^{\circ} \mathrm{C}\right)$. Seeds with endocarp were immersed in concentrated sulfuric acid for $6 \mathrm{~h}$, then soaked in hot water $\left(80^{\circ} \mathrm{C}\right)$ for $18 \mathrm{~h}$, and then repeatedly washed with distilled water before sowing, (iv) sulfuric acid $30 \mathrm{~min}$. Seeds with endocarp were immersed in concentrated sulfuric acid for $30 \mathrm{~min}$ and then repeatedly washed with distilled water before sowing.

Due to the scarcity of seed material this assay could not be done with $P$. latifolia seeds.

\section{Statistical analysis}

For all experiments, final germination percentage (mean value \pm standard error) and mean germination time (MGT, mean value in days \pm standard error) were calculated. The latter was determined according to the following formula: $\mathrm{MGT}=\Sigma \mathrm{DN} / \Sigma \mathrm{N}$; where D is the number of days counted from the date of sowing and $\mathrm{N}$ is the number of seeds germinated on day D (Ellis \& Roberts, 1981). The values of final germination percentages were arcsine square-root transformed and then subjected to analysis of variance (ANOVA) using SPSS (untransformed data appear in Tables). One- way factorial ANOVA was used to test the effects of the different temperature regimes and treatments before sowing on seed germination capacity. In the same way, to determine differences among scarification treatments, data were analysed by means of one-way ANOVA. Where ANOVA indicated a significant effect, a comparison of mean values was carried out through the least significant difference test (LSD). The statistical analysis of MGT values was also carried out using one-way factorial ANOVA.

\section{Results}

\section{Effect of temperature regimes}

For each species, significant differences $(P<$ 0.001 ) on the final germination percentages were noticed between the temperatures applied during the experiments (Table 1). The germination percentages reached by $P$. angustifolia seeds without endocarp after 35 days of incubation were equal to or less than $2 \%$ at the lower and higher temperatures $\left(5^{\circ} \mathrm{C}, 10^{\circ} \mathrm{C}\right.$ and $25^{\circ} \mathrm{C}$ ), the temperatures with the best results being $15^{\circ} \mathrm{C}$ and $20{ }^{\circ} \mathrm{C}(77 \%$ and $70 \%$, respectively) (Table 1, Figure 1). The final germination percentages reached by $P$. latifolia seeds without endocarp were equal to or less than $5 \%$ for all temperatures assayed except for 15 ${ }^{\circ} \mathrm{C}$ (52\%) (Table 1, Figure 1). Regarding the speed of germination (MGT), for P. angustifolia seeds, germination velocity was not significantly $(P>0.05)$ affected by the temperature regimes (Table 1, Figure 1). Thus, MGT values were similar among temperatures, ranging from 18 to 24 days. Moreover, P. angustifolia seeds showed at $15{ }^{\circ} \mathrm{C}$ a faster germination (lower MGT values) than P. latifolia seeds (20 and 29 days, respectively).

$P$. angustifolia seeds that did not germinate after being incubated at the temperature regimes of $5{ }^{\circ} \mathrm{C}, 25^{\circ} \mathrm{C}$ or $25 / 15^{\circ} \mathrm{C}$ for 35 days, were transferred to $15^{\circ} \mathrm{C}$. Germination percentage was increased in all cases, with final 
Table 1 Final germination percentage and mean germination time (MGT) for Phillyrea angustifolia and P. latifolia seeds without endocarp incubated at different temperature regimes for 35 days. Means within a column followed by the same letter are not significantly different according to the LSD test at $P>0.05$

\begin{tabular}{lllll}
\hline \multirow{2}{*}{$\begin{array}{l}\text { Temperature } \\
\left({ }^{\circ} \mathrm{C}\right)\end{array}$} & \multicolumn{2}{l}{ Phillyrea angustifolia } & \multicolumn{2}{l}{ Phillyrea latifolia } \\
\cline { 2 - 5 } & $\begin{array}{l}\text { Germination } \\
(\% \pm \mathrm{SE})\end{array}$ & $\begin{array}{l}\text { MGT } \\
(\text { days } \pm \mathrm{SE})\end{array}$ & $\begin{array}{l}\text { Germination } \\
(\% \pm \mathrm{SE})\end{array}$ & $\begin{array}{l}\text { MGT } \\
(\text { days } \pm \mathrm{SE})\end{array}$ \\
\hline 5 & $0^{\mathrm{a}}$ & - & $\mathrm{NO}$ & $\mathrm{NO}$ \\
10 & $0^{\mathrm{a}}$ & - & $5 \pm 3.53^{\mathrm{a}}$ & $\mathrm{NC}$ \\
15 & $77 \pm 5.72^{\mathrm{d}}$ & $20.35 \pm 1.20^{\mathrm{a}}$ & $52 \pm 1.06^{\mathrm{b}}$ & $29.00 \pm 0.13$ \\
20 & $70 \pm 5.92^{\mathrm{d}}$ & $23.12 \pm 0.44^{\mathrm{a}}$ & $2 \pm 1.41^{\mathrm{a}}$ & $\mathrm{NC}$ \\
25 & $2 \pm 1.73^{\mathrm{ab}}$ & $\mathrm{NC}$ & 0 & - \\
$20 / 7$ & $10 \pm 1.73^{\mathrm{b}}$ & $26.50 \pm 4.07^{\mathrm{a}}$ & $\mathrm{NO}$ & $\mathrm{NO}$ \\
$25 / 15$ & $39 \pm 3.57^{\mathrm{c}}$ & $18.22 \pm 0.57^{\mathrm{a}}$ & 0 & - \\
\hline
\end{tabular}

Note. NC: MGT value was not calculated when the final germination percentage was equal to or less than $5 \%$. NO: trial not carried out due to the scarcity of seed material.

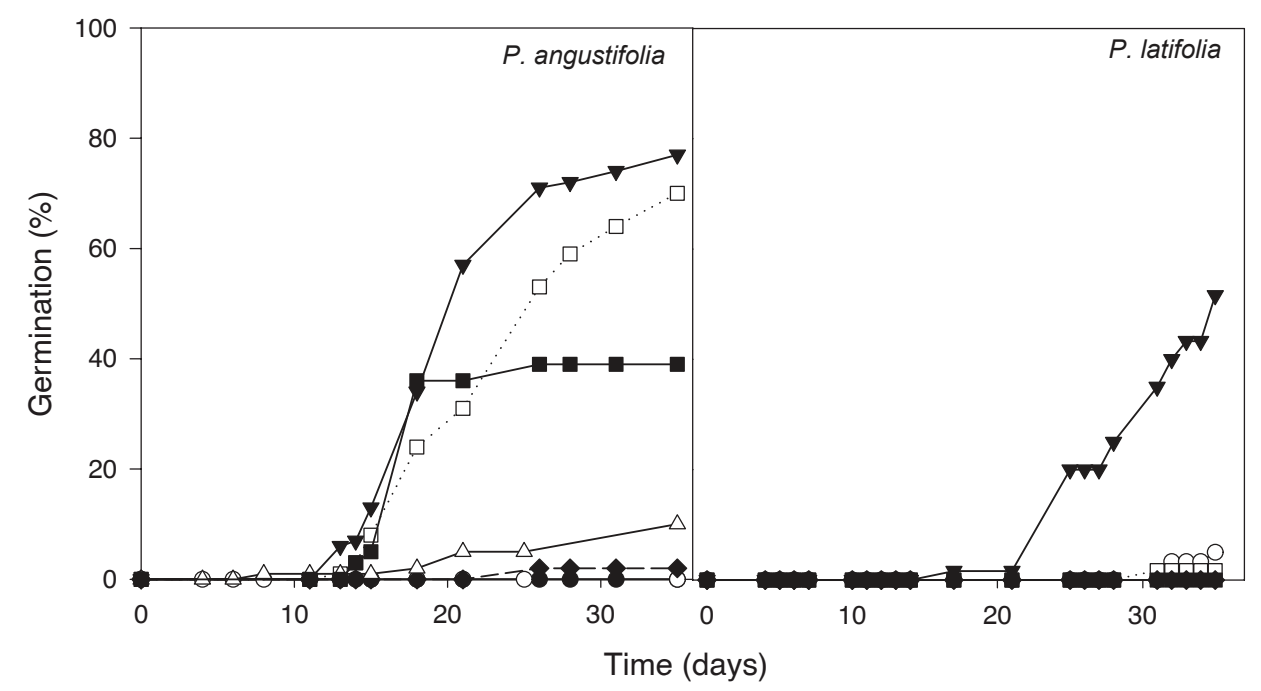

Figure 1 Germination time courses of Phillyrea angustifolia and P. latifolia seeds without endocarp incubated for 35 days at different temperature regimes: $5^{\circ} \mathrm{C}(\bullet), 10^{\circ} \mathrm{C}(\circ), 15^{\circ} \mathrm{C}(\boldsymbol{\nabla}), 20^{\circ} \mathrm{C}(\square), 25$ ${ }^{\circ} \mathrm{C}(\diamond), 20 / 7^{\circ} \mathrm{C}(\triangle)$ and $25 / 15^{\circ} \mathrm{C}(\mathbf{\bullet})$.

values being registered from $30 \%$ to $83 \%$ (Figure 2).

Final germination percentages reached by $P$. latifolia seeds with and without endocarp at different temperatures are showed in Figure 3. For P. latifolia seeds with endocarp, germination occurred only at $15{ }^{\circ} \mathrm{C}$. However, when those seeds with endocarp incubated at $10{ }^{\circ} \mathrm{C}$, $20^{\circ} \mathrm{C}, 25^{\circ} \mathrm{C}$ and $25 / 15^{\circ} \mathrm{C}$ for a 55 -day period were transferred to $15^{\circ} \mathrm{C}$ their germination increased greatly, with final values from $70 \%$ to $85 \%$. P. latifolia seeds without endocarp that were moved to $15^{\circ} \mathrm{C}$ after a 55-day period of incubation at $10^{\circ} \mathrm{C}, 20^{\circ} \mathrm{C}, 25^{\circ} \mathrm{C}$ and $25 / 15^{\circ} \mathrm{C}$ increased their germination percentage from $60 \%$ to $87 \%$ after another 137 -day period. 


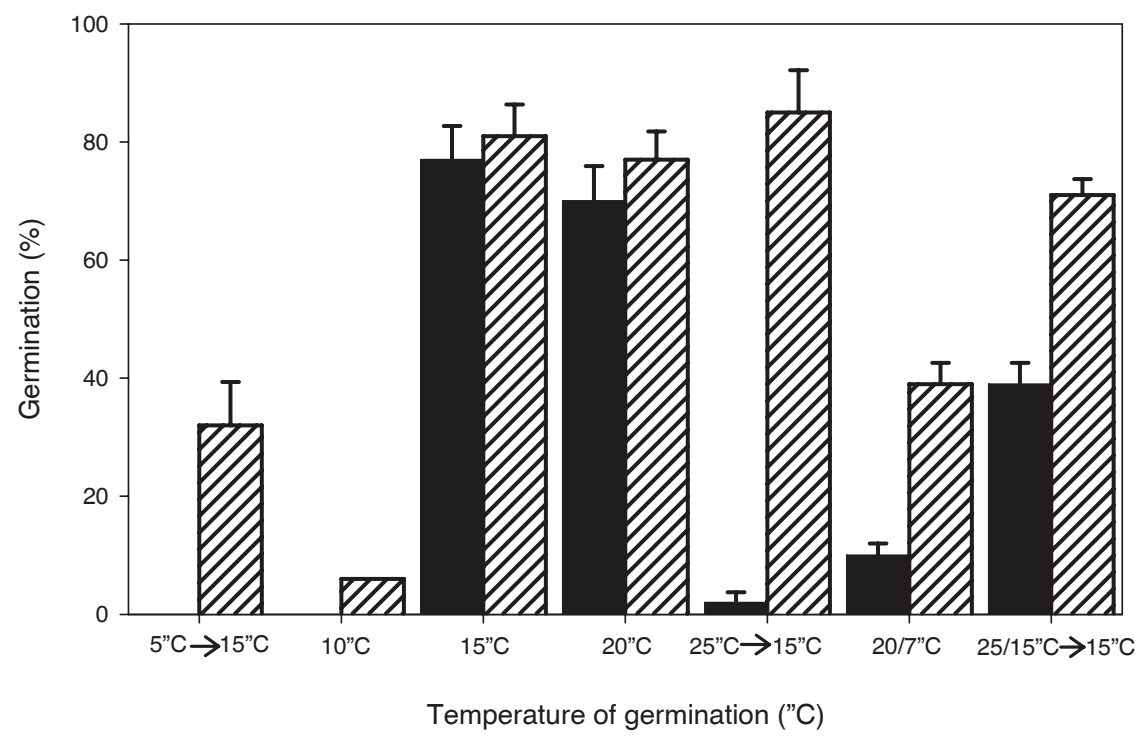

Figure 2 Final germination percentages of Phillyrea angustifolia seeds without endocarp incubated at different temperature regimes. Seeds were incubated for 35 days and then those at $5{ }^{\circ} \mathrm{C}, 25^{\circ} \mathrm{Cand}$ $25 / 15^{\circ} \mathrm{C}$ were transferred to $15^{\circ} \mathrm{C}$ for another 35 -day period. Filled bars represent final germination ( \pm standard error) at the indicated temperature after 35 days and striped bars after another 35-day period.

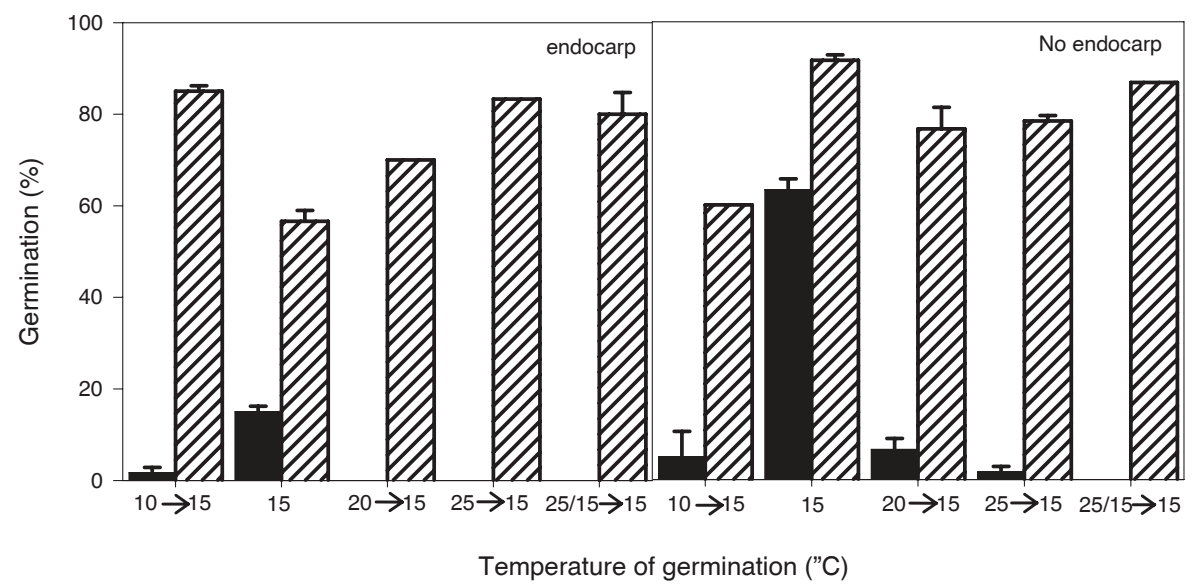

Figure 3 Final germination percentage of Phillyrea latifolia seeds with and without endocarp incubated at different temperatures for 55 days and then transferred to $15^{\circ} \mathrm{C}$ for another 137-day period. Filled bars represent final germination ( \pm standard error) at the indicated temperature after 55 days and striped bars after another 137-day period.

\section{Treatments before sowing}

The effect of different treatments before sowing on germination of $P$. angustifolia and $P$. latifolia seeds is shown in Table 2 and Figure 4. For $P$. angustifolia seeds, no significant differences $(P>0.05)$ were found among the final germination percentages reached by con- trol seeds (untreated seeds) and seeds soaked in distilled water or $\mathrm{GA}_{3}$. However, stratification of $P$. angustifolia seeds at $5{ }^{\circ} \mathrm{C}$ for 90 days significantly $(P<0.001)$ decreased the final germination percentage when compared to the control ( $9 \%$ vs. $81 \%$, respectively). Germination speed was not significantly $(P>0.05)$ increased by the different treatments before 
sowing assayed. For $P$. angustifolia seeds, all treatments significantly $(P<0.001)$ reduced the final germination percentages. Germination speed was higher for $P$. latifolia seeds soaked for $24 \mathrm{~h}$ and $72 \mathrm{~h}$ in distilled water than that of control seeds, but these differences were not significant $(P>0.05)$.

\section{Water uptake}

P. latifolia seeds without endocarp absorbed water quickly after $24 \mathrm{~h}$ immersion in distilled water (Figure 5), being registered seed mass increasing with $60 \%$ of the initial value. $P$. latifolia seeds with endocarp also absorbed water but at a lower rate. Thus, mean increase in mass for seeds without endocarp after $24 \mathrm{~h}$ was more than twice of that in seeds with endocarp (26\%). After $48 \mathrm{~h}$, seed mass increase was $67 \%$ in seed without endocarp, and $39 \%$ in seeds with endocarp. After $72 \mathrm{~h}$ of immersion in distilled water, seed mass increase was $68 \%$ in seed without endocarp, and $47 \%$ in seed with endocarp.

\section{Scarification treatments}

$P$. angustifolia seeds whose endocarp was cracked but not totally removed and seeds submerged in concentrated sulfuric acid showed a similar germination (22-26\%), significantly
$(P<0.001)$ lower than that of seeds without endocarp (81\%) (Table 3). Germination speed was significantly $(P<0.001)$ higher for seeds scarified with sulphuric acid for $6 \mathrm{~h}$ than that of control seeds (3.4 days vs. 20.8 days, respectively).

\section{Discussion}

Regeneration potential of Phillyrea species depends on the effect of ambient conditions on its propagation process, and knowledge of the germination requirements would be fundamental for the conservation of this species. Our results indicate that Phillyrea species germination is slow. The highest germination percentage after a 35 -day period was obtained at $15^{\circ} \mathrm{C}$ for both species, being maximum germination $77 \%$ for $P$. angustifolia and $52 \%$ for P. latifolia . Also, temperature regime for $P$. latifolia was very restrictive, since seeds did not germinate at either $25^{\circ} \mathrm{C}$ or $25 / 15^{\circ} \mathrm{C}$. These results are in agreement with optimal germination temperature for most Mediterranean shrub species ranging between $15^{\circ} \mathrm{C}$ and $20^{\circ} \mathrm{C}$ (Thanos et al. 1992, 1995). Alternating temperatures (20/7 ${ }^{\circ} \mathrm{C}$ and $25 / 15^{\circ} \mathrm{C}$ ) resulted in low germination percentages, although previous works stated that Phillyrea seeds germinated a $90 \%$ after 60 days at $20 / 7^{\circ} \mathrm{C}$ (Herranz et al. 2006), or a $90 \%$

Table 2 Final germination percentage and mean germination time (MGT) of Phillyrea angustifolia and $P$. latifolia seeds without endocarp after several treatments before sowing. Seeds were germinated at $15^{\circ} \mathrm{C}$ for 65 days. Untreated seeds without endocarp were used as control. Means within a column followed by the same letter are not significantly different according to the LSD test at $P>0.05$.

\begin{tabular}{lllll}
\hline \multirow{2}{*}{ Treatment before sowing } & \multicolumn{2}{l}{ Phillyrea angustifolia } & \multicolumn{2}{l}{ Phillyrea latifolia } \\
\cline { 2 - 5 } & $\begin{array}{l}\text { Germination } \\
(\% \pm \mathrm{SE})\end{array}$ & $\begin{array}{l}\text { MGT } \\
(\text { days } \pm \mathrm{SE})\end{array}$ & $\begin{array}{l}\text { Germination } \\
(\% \pm \mathrm{SE})\end{array}$ & $\begin{array}{l}\text { MGT } \\
(\text { days } \pm \mathrm{SE})\end{array}$ \\
\hline Control & $81 \pm 5.36^{\mathrm{b}}$ & $20.85 \pm 0.86^{\mathrm{a}}$ & $62 \pm 5.20^{\mathrm{b}}$ & $32.57 \pm 2.19^{\mathrm{a}}$ \\
Soaking in distilled water for 24 h & $84 \pm 5.48^{\mathrm{b}}$ & $16.20 \pm 0.74^{\mathrm{a}}$ & $14 \pm 1.73^{\mathrm{a}}$ & $31.12 \pm 1.64^{\mathrm{a}}$ \\
$72 \mathrm{~h}$ & $86 \pm 4.58^{\mathrm{b}}$ & $12.67 \pm 0.19^{\mathrm{a}}$ & $10 \pm 1.95^{\mathrm{a}}$ & $29.00 \pm 2.50^{\mathrm{a}}$ \\
Soaking in GA & $79 \pm 3.84^{\mathrm{b}}$ & $16.17 \pm 0.48^{\mathrm{a}}$ & $21 \pm 6.98^{\mathrm{a}}$ & $39.62 \pm 0.92^{\mathrm{ab}}$ \\
Stratification at $5{ }^{\circ} \mathrm{C}$ 30 days & NO & NO & $12 \pm 0.65^{\mathrm{a}}$ & $56.50 \pm 0.56^{\mathrm{c}}$ \\
90 days & $9 \pm 2.17^{\mathrm{a}}$ & $19.12 \pm 6.32^{\mathrm{a}}$ & $17 \pm 2.98^{\mathrm{a}}$ & $52.25 \pm 4.42^{\mathrm{bc}}$ \\
\hline Note NO: trial not carried out due to the scarcity of seed material.
\end{tabular}

Note. NO: trial not carried out due to the scarcity of seed material. 


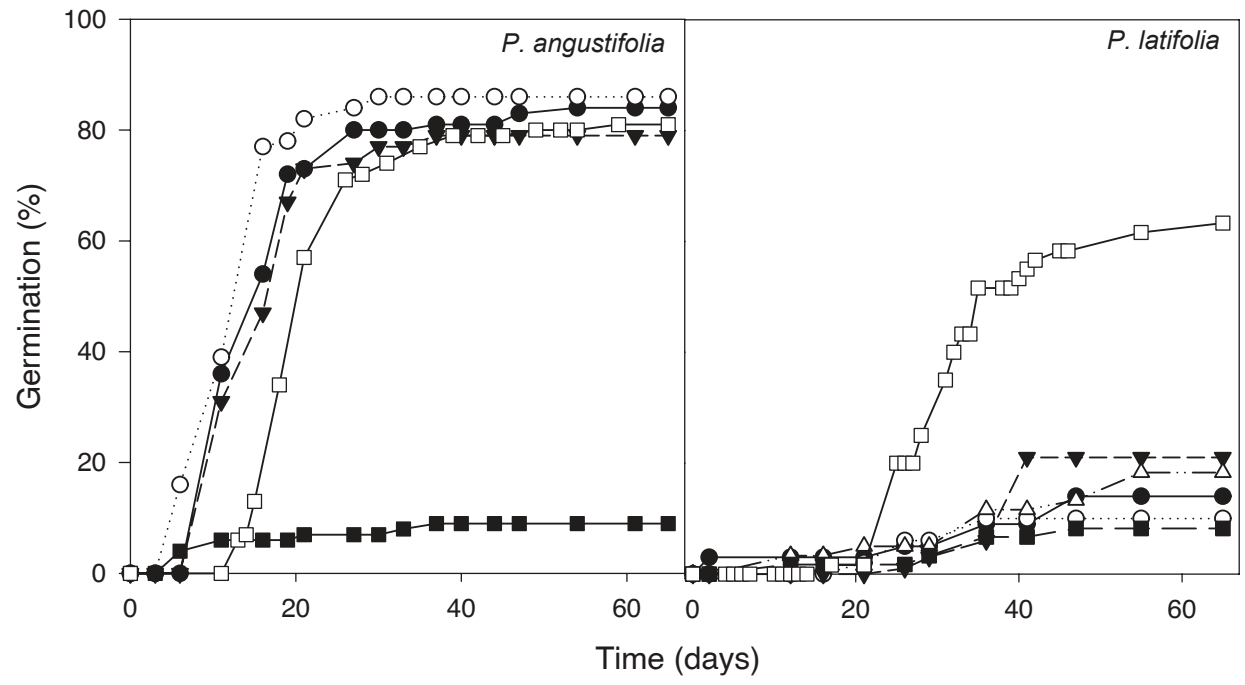

Figure 4 Germination time courses of Phillyrea angustifolia and P. latifolia seeds without endocarp after different treatments before sowing: control ( $\square$ ), soaking in distilled water for $24 \mathrm{~h}(\bullet)$, soaking in distilled water for $72 \mathrm{~h}(\mathrm{O})$, soaking in a $\mathrm{GA}_{3}$ solution $\left(1000 \mathrm{mg} \mathrm{L}^{-1}\right)$ for $24 \mathrm{~h}(\boldsymbol{\nabla})$, cold stratification at $5{ }^{\circ} \mathrm{C}$ for 30 days $(\triangle)$ and 90 days $(\boldsymbol{\square})$. Seeds were incubated at $15^{\circ} \mathrm{C}$ for 65 days

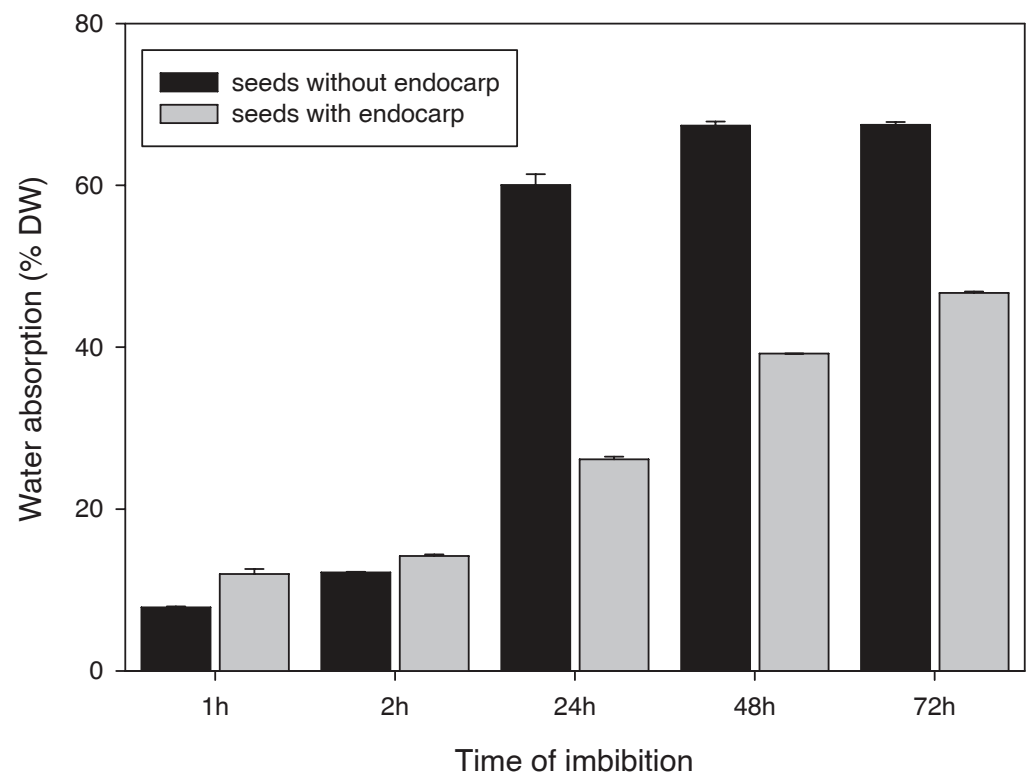

Figure 5 Mean ( \pm standard error) increase in mass of Phillyrea latifolia seeds with and without endocarp placed on filter paper moistened with distilled water at $\sim 23^{\circ} \mathrm{C}$.

after 15 days at $20 / 10{ }^{\circ} \mathrm{C}$ (García-Fayos et al. 2001). This could indicate a variation of the optimal germination temperatures for different populations of the same species. One of the most important survival adaptations for plant species growing under variable and unpredictable environmental conditions, as in the Mediterranean forests, is the intraspecific variation of germination requirements (Kigel 1995,
Baskin \& Baskin 1998, Martínez-García et al. 2012), concerning the seed dormancy (PérezGarcía et al. 2012), or seed longevity (Lazar et al. 2014, Mira et al. 2011a, 2011b, 2014). However, in some forest species, as Populus euphratica and Pinus nigra, it has been shown that source origin had minimal influence on seed germination or seedling quality (Ivetic \& Skoric 2013, Soleimani et al. 2014). 
It is known that some seeds with lignified endocarp germinate well following cold stratification (Baskin et al. 2002), however, cold stratification of Phillyrea seeds was detrimental for seed germination. Incubation at low temperatures $\left(5^{\circ} \mathrm{C}\right.$ for $P$. angustifolia and $10{ }^{\circ} \mathrm{C}$ for $P$. latifolia) seemed to induce a secondary dormancy, since final germination did not achieve maximum values when seeds were transferred to $15^{\circ} \mathrm{C}$. The inefficiency of a cold stratification treatment agrees with previous work in Phillyrea species (García-Fayos et al. 2001), but it is a especially interesting result since cold stratification is a common treatment for forestry species and some seed producing companies recommend it for these particular species. On the other side, seed incubation at high temperatures, $25^{\circ} \mathrm{C}$ and $25 / 15^{\circ} \mathrm{C}$, resulted in a low germination percentage for both species but did not induce dormancy.

Treatments before sowing through soaking in distilled water or in a gibberellic acid solution did not significantly increase final germination for $P$. angustifolia seeds, and they were clearly detrimental for P. latifolia. Moreover, acid scarification with sulfuric acid registered very poor results in $P$. angustifolia, which is especially meaningful since this technique has been suggested as one of the best to promote germination in several species with lignified endocarp (Bonner \& Karrfalt 2008), and it has been previously recommended for Phillyrea species by seed producing companies and previous reports (Piotto \& Di Noi 2003, Bacchetta et al. 2008). These contradictory results could be explained by an inter- and intra-population variability on the endocarp permeability and hardness in Phillyrea species, as has been previously suggested (Traveset et al. 2007, Arnal 2013). In our study, P. latifolia seeds with endocarp absorbed water during soaking, although more slowly than in seeds without endocarp. This results would indicate that $P$. latifolia seeds do not exhibit physical dormancy, according to the classification system of Baskin \& Baskin (2004), were physical dormancy is defined as the result of a water-impermeable layer in the seed or fruit. Similar results had been reported in several species with lignified endocarp (Baskin et al. 2002) and some species within the Oleaceae family, like Olea sp. (Cuneo et al. 2010).

Total removal of the endocarp with pliers was the technique that showed best results regarding germination of $P$. angustifolia, while this morpho-physiological process was not promoted when endocarp was cracked. Moreover, P. latifolia seeds with endocarp incubated at 10 ${ }^{\circ} \mathrm{C}, 20^{\circ} \mathrm{C}, 25^{\circ} \mathrm{C}$ or $25 / 15^{\circ} \mathrm{C}$ did not germinate for 55 days, but achieved high germination percentages when transferred at $15^{\circ} \mathrm{C}$. Other authors found that seeds of $P$. latifolia collected from the soil in previous years showed a high germination (Yucedag \& Gultekin 2011), and that Olea europaea seed germination in the soil did not occur until complete decomposition of the endocarp (Cuneo et al. 2010). Our results suggest that Phillyrea species may present a lignified endocarp that interferes mechanically in the emergence of the radicle but not in the absorption of water, and that complete removal of endocarp is necessary to achieve the full

Table 3 Final germination percentage and mean germination time (MGT) for Phillyrea angustifolia seeds after several scarification treatments. Seeds were incubated at $15{ }^{\circ} \mathrm{C}$ for 75 days. Means within a column followed by the same letter are not significantly different according to the LSD test at $P$ $>0.05$.

\begin{tabular}{lll}
\hline Scarification treatment & Germination $(\% \pm \mathrm{SE})$ & MGT $($ days $\pm \mathrm{SE})$ \\
\hline Endocarp removed with pliers & $81 \pm 5.36^{\mathrm{b}}$ & $20.85 \pm 0.86^{\mathrm{b}}$ \\
Endocarp cracked & $22 \pm 2.24^{\mathrm{a}}$ & $48.42 \pm 3.32^{\mathrm{d}}$ \\
$\mathrm{SO}_{4} \mathrm{H}_{2}(6 \mathrm{~h})+$ hot water $\left(80^{\circ} \mathrm{C}\right)$ & $22 \pm 4.58^{\mathrm{a}}$ & $3.37 \pm 0.27^{\mathrm{a}}$ \\
$\mathrm{SO}_{4} \mathrm{H}_{2}(30 \mathrm{~min})$ & $26 \pm 8.18^{\mathrm{a}}$ & $34.75 \pm 1.08^{\mathrm{c}}$ \\
\hline
\end{tabular}


germination. In nature, Phillyrea fruits spread in winter, their seeds remaining in the soil and with time the endocarp might degenerate allowing seeds to germinate during the period of early spring temperatures and rains.

\section{Conclusions}

Our data provided useful information in germination protocols for Phillyrea species propagation. Optimal germination temperature for Phillyrea species was $15{ }^{\circ} \mathrm{C}$, lower temperatures resulting in secondary dormancy. Treatments of cold stratification, soaking in distilled water or gibberellic acid did not improve seed germination. Our results proved that $P$. latifolia endocarp was permeable to water but could mechanically interfere with the radicle emergence, and total removal of the endocarp was the technique that showed best results for seed germination improving.

\section{Acknowledgement}

Authors would like to thank Carlos Ruiz for his help on seed collecting. Semillas Montaraz Company donated seed material. Luciana Veiga-Barbosa was supported by a grant from Fundación Carolina (Spain).

\section{References}

Andrés C., 2011. Phillyrea L. In: Castroviejo S., Aedo C., Cirujano S., Laínz M., Montserrat P., Morales R., Muñoz F., Navarro C., Paiva J., Soriano C., (eds.), Flora Iberica. Vol. 11. Madrid, Spain: Real Jardín Botánico de Madrid, CSIC, pp. 139-143.

Arnal A., 2013. Germination and Conservation of narrow leaf Phillyrea seeds (Phillyrea angustifolia L.) [Germinación y Conservación de Semillas de Labiérnago (Phillyrea angustifolia L.) (Oleaceae)]. Master's thesis. Máster Universitario en Recursos Fitogenéticos. Madrid, Spain: Escuela Técnica Superior de Ingenieros Agrónomos, Universidad Politécnica de Madrid. pp. 58.

Bacchetta G., Bueno A., Sánchez G., Fenu G., JiménezAlfaro B., Mattana E., Piotto B., Virevaire M., 2008. Ex Situ Conservation of Wild Plants [Conservación Ex Situ de Plantas Silvestres]. Asturias, Spain: Principado de Asturias/La Caixa. 378 pp. Anexo Digital I. pp. 15.

Baskin C.C., Baskin J.M., 1998. Seeds: Ecology, biogeography, and evolution of dormancy and germination. London, UK: Academic Press, pp. 37-39.

Baskin J.M., Baskin C.C., 2004. A classification system for seed dormancy. Seed Science Research 14: 1-16. DOI: 10.1079/ SSR2003150.

Baskin C.C., Zackrisson O., Baskin J.M., 2002. Role of warm stratification in promoting germination of seeds of Empetrum hermaphroditum (Empetraceae), a circumboreal species with a stony endocarp. American Journal of Botany 89: 486-493. DOI: 10.3732/ ajb.89.3.486.

Bonner F.T., Karrfalt R., 2008. The woody plant seed manual. Agric. Handbook No. 727. Washington, DC. U.S. Department of Agriculture, Forest Service. pp. 107.

Catalán G., 1991. Phillyrea. In: Forest Tree and Shrub Seeds [Semillas de Árboles y Arbustos Forestales] Catalán G., (ed.) Madrid, Spain: Instituto Nacional para la Conservación de la Naturaleza, pp. 265-266.

Chaves M.M., Pereira J.S., Maroco J., Rodrigues M.L., Ricardo C.P.P., Osorio M.L., Carvalho I., Faria T., Pinheiro C., 2002. How plants cope with water stress in the field?. Photosynthesis and growth. Annals of Botany 89: 907-916. DOI: 10.1093/aob/mcf105.

Christensen J.H., Hewitson B., Busuioc A., Chen A., Gao X., Held I., Jones R., Kolli R.K., Kwon W.T., Laprise R., et al. 2007. Regional climate projections. In: Solomon S., Qin D., Manning M., Chen Z., Marquis M., Averyt K.B., Tignor M., Miller H.L., (eds.) Climate Change 2007: The physical science basis. Contribution of working group to the fourth assessment report of the intergovernmental panel on climate change. Cambridge, UK: Cambridge University Press, pp. 847-940.

Cuneo P., Offord C.A., Leishman M.R., 2010. Seed ecology of the invasive woody plant African Olive (Olea europaea subsp. cuspidata): implications for management and restoration. Australian Journal of Botany 58: 342-348. DOI: 10.1071/BT10061.

Demmig-Adams B., Adams III W.W., 1996. The role of xanthophyll cycle carotenoids in the protection of photosynthesis. Trends in Plant Science 1: 21-26. DOI: 10.1016/S1360-1385(96)80019-7.

De Marco A., Gentile A.E., Arena C., De Santo A.V., 2005. Organic matter, nutrient content and biological activity in burned and unburned soils of a Mediterranean maquis area of southern Italy. International Journal of Wildland Fire 14: 365-377. DOI: 10.1071/ WF05030.

Dimitrakopoulos A.P., Mitsopoulos I.D., Kaliva A., 2013. Short communication. Comparing flammability traits among fire-stricken (low elevation) and non fire- stricken (high elevation) conifer forest species of Europe: a test of the Mutch hypothesis. Forest System 22: 134137. DOI: $10.5424 / \mathrm{fs} / 2013221-02475$.

Ellis R.H., Roberts E.H., 1981. The quantification of ageing and survival in orthodox seeds. Seed Science and Technology 9: 373-409.

García-Fayos P., Gulias J., Martínez J., Marzo A., Melero 
J.P., Traveset A., 2001. Ecological Basis for Forest Tree Seed Collection, Storage and Germination of the Valencian Community [Bases Ecológicas para la Recolección, Almacenamiento y Germinación de Semillas de Especies de Uso Forestal de la Comunidad Valenciana. Comunidad Valenciana], Spain: IMEDEA, Banc de Llavors Forestals. pp 29-30.

Herranz J.M., Ferrandis P., Copete M.A., Duro E.H., Zalacain A., 2006. Effect of allelopathic compounds produced by Cistus ladanifer on germination of 20 Mediterranean taxa. Plant Ecology 184: 259-272. DOI: 10.1007/s11258-005-9071-6.

Herrera C.M., Jordano P., López Soria L., Amat J.A., 1994. Recruitment of a mast-fruiting, bird-dispersed tree-bridging frugivore activity and seedling establishment. Ecology Monographies 64: 315-344. DOI: 10.2307/2937165.

Ivetic V., Skoric M., 2013. The impact of seeds provenance and nursery production method on Austrian pine (Pinus nigra Arn.) seedlings quality. Annals of Forest Research 56: 297-305.

Kigel J., 1995. Seed germination in arid and semiarid regions. In: Kigel J, Galili G. (eds.), Seed development and germination. New York, USA: Marcel Dekker, pp 645-699.

Kutbay H.G., Kilinç M., 1994. Sclerophylly in Quercus cerris L. var. cerris and Phillyrea latifolia L. and edaphic relations of these species. Species Vegetatio 113(2): 93-97.

Lazar S.L., Mira S., Pamfil D., Martínez-Laborde J.B., 2014. Germination and electrical conductivity tests on artificially aged seed lots of 2 wall-rocket species. Turkish Journal of Agriculture and Forestry 38. DOI: 10.3906/tar-1402-76.

Martínez-García F., Guerrero-García S., Pérez-García F., 2012. Evaluation of reproductive success and conservation strategies for Senecio coincyi (Asteraceae), a narrow and threatened species. Australian Journal of Botany 60: 517-525. DOI: 10.1071/BT12109.

Mira S., Estrelles E., Gonzalez-Benito M.E., Corbineau F., 2011a. Biochemical changes induced in seeds of Brassicaceae wild species during ageing. Acta Physiologia Plantarum 33: 1803-1809. DOI: 10. 1007/s11738-0110719-7.

Mira S., González-Benito M.E., Ibars A.M., Estrelles E., 2011b. Dormancy release and seed ageing in the endangered species Silene diclinis. [Biodiversty and Conservation] 20: 345-358. DOI: 10.1007/s10531-010-9833$\mathrm{x}$.

Mira S., Estrelles E., Gonzalez-Benito M.E., 2015. Effect of water content and temperature on seed longevity of seven Brassicaceae species after 5 years storage. Plant Biology 17: 153-162. DOI: 10.1111/plb.12183

Mitrakos K., Diamantoglou S., 1984. Endosperm dormancy breakage in olive seeds. Physiologia Plantarum 62:
8-10. DOI: 10.1111/j.1399-3054.1984.tb05915.x.

Morales-Sillero A., Suarez M.P., Jiménez M.R., Casanova L., Ordovas J., Rallo P., 2012. Olive seed germination and initial seedling vigor as influenced by stratification treatment and the female parent. Hortscience 47: 16721678 .

Pardos M., Montero G., Cañellas I., Ruiz del Castillo J., 2005. Ecophysiology of natural regeneration of forest stands in Spain. Forest Systems 14: 434-445.

Pausas J., Llovet J., Rodrigo A., Vallejo R., 2008. Are wildfires a disaster in the Mediterranean basin?- A review. International Journal of Wildland Fire 17: 713 723. DOI: 10.1071/WF07151.

Pérez-García F., Varela F., González-Benito M.E., 2012. Morphological and germination response variability in seeds of wild yellow gentian (Gentiana lutea L.) accessions from northwest Spain. Botany 90: 731-742. DOI: 10.1139/b2012-028.

Piñol J., Terradas J., Lloret F., 1998. Climate warming, wildfire hazard, and wildfire occurrence in Coastal Eastern Spain. Climatic Change 38: 345-357. DOI: 10.1023/A:1005316632105.

Piotto B., Di Noi A., 2003. Seed Propagation of Mediterranean Trees and Shrubs [Propagazione per Seme di Alberi e Arbusti della Flora Mediterranea]. Rome, Italy: Agenzia Nazionale per la protezione dell'Ambiente (ANPA), pp. 138.

Soleimani A., Etemad V., Calagari M., Namiranian M., Shirvani A., 2014. Influence of climatic factors on fruit morphological traits in Populus euphratica Oilv. Annals of Forest Research 57: 31-38. DOI: 10.15287/ afr.2014.188.

Takos I.A., Efthimiou G.S., 2003. Germination results on dormant seeds of fifteen tree species autumn sown in a northern Greek nursery. Silvae Genetica 52: 67-71.

Thanos C.A., Georghiou K., Kadis C.C., Pantazi C., 1992. Cistaceae: a plant family with hard seeds. Israel Journal of Botany 41: 251-263.

Thanos C.A., Kadis C.C., Skarou F., 1995. Ecophysiology of germination in the aromatic plants thyme, savory and C. ladanifer. International Journal of Wildland Fire 2: 15-20.

Traveset A., Robertson Q.W., Rodríguez-Pérez J., 2007. A review on the role of endozoochory in seed germination. In: Dennis AJ, Schupp EW, Green RA, Westcott DA, (eds.), Seed dispersal, theory and its application in a changing world. London, UK: CABI International, pp. 78-103. DOI: 10.1079/9781845931650.0078.

Varela M.C., 2000. Mediterranean oaks. EUFORGEN Genetic Conservation Network. Forest Systems 9: 95102.

Yucedag C., Gultekin H.C., 2011. Effects of fruit collection date on Phillyrea latifolia L. seed germination. Pakistan Journal of Biological Sciences 14: 785-787. DOI: $10.3923 /$ pjbs.2011.785.787. 
